\title{
Tidal modulation of infragravity waves via nonlinear energy losses in the surfzone
}

\author{
Jim Thomson, ${ }^{1}$ Steve Elgar, ${ }^{1}$ Britt Raubenheimer, ${ }^{1}$ T. H. C. Herbers, ${ }^{2}$ and R. T. Guza ${ }^{3}$ \\ Received 28 December 2005; revised 26 January 2006; accepted 31 January 2006; published 1 March 2006.
}

[1] The strong tidal modulation of infragravity (200 to $20 \mathrm{~s}$ period) waves observed on the southern California shelf is shown to be the result of nonlinear transfers of energy from these low-frequency long waves to higher-frequency motions. The energy loss occurs in the surfzone, and is stronger as waves propagate over the convex low-tide beach profile than over the concave high-tide profile, resulting in a tidal modulation of seaward-radiated infragravity energy. Although previous studies have attributed infragravity energy losses in the surfzone to bottom drag and turbulence, theoretical estimates using both observations and numerical simulations suggest nonlinear transfers dominate. The observed beach profiles and energy transfers are similar along several $\mathrm{km}$ of the southern California coast, providing a mechanism for the tidal modulation of infragravity waves observed in bottom-pressure and seismic records on the continental shelf and in the deep ocean. Citation: Thomson, J., S. Elgar, B. Raubenheimer, T. H. C. Herbers, and R. T. Guza (2006), Tidal modulation of infragravity waves via nonlinear energy losses in the surfzone, Geophys. Res. Lett., 33, L05601, doi:10.1029/2005GL025514.

\section{Introduction}

[2] Infragravity surface waves (periods between 200 and $20 \mathrm{~s}$ ) are observed throughout the deep [Webb et al., 1991] and coastal [Munk et al., 1956; Tucker, 1950] oceans, and are strongest near the shoreline (Guza and Thornton [1985], Elgar et al. [1992], and many others), where they force circulation [Kobayashi and Karjadi, 1996] and transport sediment [Holman and Bowen, 1982]. Although infragravity motions complicate seismic monitoring [Dolenc et al., 2005], they may be useful for tsunami detection [Rabinovich and Stephenson, 2004].

[3] It is well known that infragravity motions are generated by nonlinear interactions between higher-frequency (periods between 20 and $5 \mathrm{~s}$ ) wind waves [Longuet-Higgins and Stewart, 1962; Herbers et al., 1995a], but the causes of energy loss are not understood. Previous studies have attributed infragravity energy loss to bottom drag [Raubenheimer et al., 1995; Henderson and Bowen, 2002] and to breaking [Van Dongeren et al., 2004].

[4] Tidally-modulated infragravity motions have been observed on the inner-shelf [Okihiro and Guza, 1995], and in regional seismic records [Dolenc et al., 2005],

\footnotetext{
${ }^{1}$ Woods Hole Oceanographic Institution, Woods Hole, Massachusetts, USA.

${ }^{2}$ Naval Postgraduate School, Monterey, California, USA.

${ }^{3}$ Scripps Institution of Oceanography, La Jolla, California, USA.
}

Copyright 2006 by the American Geophysical Union. 0094-8276/06/2005GL025514\$05.00 possibly contributing to free oscillations of the Earth [Rhie and Romanowicz, 2004; Tanimoto, 2005]. The reduced infragravity energy observed at low tide has been hypothesized to originate near the shoreline, where tidal variations of the surfzone width and beach slope might affect infragravity generation, dissipation, or reflection [Okihiro and Guza, 1995].

[5] Here, new observations of a tidal modulation on the southern California coast (Figure 1) confirm a nearshore origin, and show that the primary cause is an enhancement of energy loss over the low-tide surfzone bottom profile. Infragravity energy is transferred to higher-frequency motions in the surfzone through near-resonant nonlinear interactions between triads of wave components (i.e., a reversal of the infragravity generation mechanism). These nonlinear transfers are sensitive to the surfzone bottom profile, and thus tidal sea level variations over the nonuniform beach produce tidal changes in the infragravity energy observed offshore (Figure 1). Recent analysis of observations from a North Carolina beach also demonstrate nonlinear infragravity losses, but without a tidal modulation of infragravity energy (S. M. Henderson et al., Nonlinear generation and loss of infragravity wave energy, submitted to Journal of Geophysical Research, hereinafter referred to as Henderson et al., submitted manuscript, 2006).

\section{Field Observations}

[6] Measurements of surface-wave-induced pressure and velocity were collected (at $2 \mathrm{~Hz}$ ) along a cross-shore transect extending from $15-\mathrm{m}$ water-depth to the shoreline near Torrey Pines State Beach in southern California (Figure 2c). Assuming shore-normal wave propagation, shoreward $\left(F^{+}\right)$and seaward $\left(F^{-}\right)$infragravity energy fluxes were estimated from the observations of pressure $(P)$ and cross-shore velocity $(U)$ as [Sheremet et al., 2002]

$$
F^{ \pm}=\frac{\sqrt{g h}}{4} \int\left(P P+\frac{h}{g} U U \pm \sqrt{\frac{4 h}{g}} P U\right) d f,
$$

where $P P(f)$ and $U U(f)$ are the auto-spectra of pressure and cross-shore velocity, respectively, $P U(f)$ is the crossspectrum of pressure and cross-shore velocity, and the integral is over the infragravity frequency $(f)$ range $(0.005<$ $f<0.05 \mathrm{~Hz}$ ). In the linear, shallow-water approximation the group velocity is given by $C_{g}=\sqrt{g h}$, where $g$ is gravitational acceleration and $h$ is the water depth.

[7] The infragravity variance of the 1-hr records observed in 15-m water depth (Figure 2c) is correlated with the tide (Figure 1). Averaged over the 50-day deployment, the infragravity variance at low tide was about $1 / 4$ the variance at adjacent high tides, although larger modulations and 


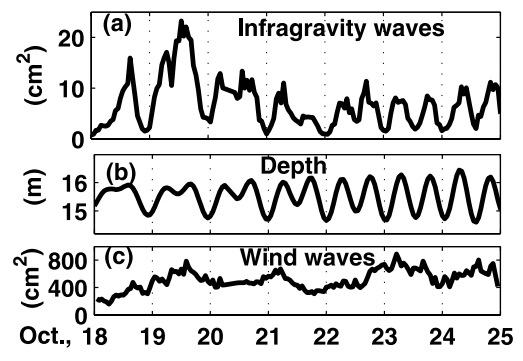

Figure 1. (a) Infragravity wave $(0.005<f<0.05 \mathrm{~Hz})$ variance $\left(\mathrm{cm}^{2}\right)$, (b) water depth $(\mathrm{m})$, and (c) wind wave $(0.05<f<0.25 \mathrm{~Hz})$ variance $\left(\mathrm{cm}^{2}\right)$ versus time. The hourly values are from a pressure gage mounted near the seafloor in 15-m water depth, $750 \mathrm{~m}$ from the shoreline on the southern California coast, $3 \mathrm{~km}$ north of the Scripps pier. The infragravity variance is correlated $\left(r^{2}=0.7\right.$ for the data shown here, and $r^{2}=0.6$ for the 50-day period [Oct-Nov 2003]) and in phase with the diurnal and semi-diurnal tides, and is only weakly correlated $\left(r^{2}=0.3\right.$ here and for all the data) with the variance of the wind waves (although the correlation $\left[r^{2}=0.6\right]$ with swell $[0.05<f<0.10 \mathrm{~Hz}]$ is higher). Time series from the rest of the 50-day deployment are similar.

other variability are present (e.g., October 19 and 20, Figure 1).

[8] Infragravity wave energy can be trapped near the shore as low-mode edge waves [Huntley et al., 1981; Oltman-Shay and Guza, 1987], and may include contributions from shear instabilities of the alongshore current [Oltman-Shay et al., 1989; Bowen and Holman, 1989]. These processes were neglected here, because the tidal modulation was observed far offshore of the trapping region, and the records $(20 \%$ of the total) for which shear instabilities contributed more than $30 \%$ of the total infragravity velocity variance [Lippmann et al., 1999] were excluded.

[9] The cross-shore structure of the observed infragravity energy fluxes (Figure 2) suggests that the reduction in total (shoreward plus seaward) infragravity variance offshore of the surfzone (approximately $x>100 \mathrm{~m}$ in Figure 2) at low tide is caused by a reduction in $F^{-}$. In the surfzone, $F^{-}$ originates primarily from shoreline reflection of $F^{+}$(Guza and Thornton [1985], Elgar et al. [1994], and others). However, reflection coefficients $\left(R^{2}=\frac{F^{-}}{F^{+}}\right)$estimated from observations at the most shoreward instrument are approximately 1 regardless of the tide (not shown), suggesting the offshore tidal modulation of $F^{-}$must be caused by a surfzone modulation of $F^{+}$. Outside the surfzone, shoreward infragravity energy flux $F^{+}$, which contains contributions from remote sources [Elgar et al., 1992; Herbers et al., $1995 \mathrm{~b}]$ and from local generation by nonlinear interactions with wind waves $(0.05>f>0.25 \mathrm{~Hz})$ [Herbers et al., 1995a], is similar at low and high tides (Figure 2a). Thus, the tidal modulation of infragravity variance appears to arise from a tidal modulation of the shoreward-propagating waves inside the surfzone before waves reflect from the beach (Figure 2a).

\section{Analysis}

[10] To compare low- with high-tide observations, instrument locations are normalized by the width of the surfzone for each record, so that the nondimensional cross-shore coordinate $x_{S z}$ is 0 where the mean sea-surface intersects the shoreline, and is 1 at the seaward edge of the surfzone (defined as the location where the incoming wind-wave energy flux [equation (1) integrated over $0.05<f<0.25 \mathrm{~Hz}$ ] drops below $85 \%$ of the flux in $15-\mathrm{m}$ water depth). Crossshore gradients $\frac{d}{d x}$ of the infragravity energy fluxes $F^{ \pm}$ (equation (1)) are calculated dimensionally using the difference between adjacent observations, and then are mapped to the normalized coordinate. Energy flux is conserved by linear shoaling waves, and nonzero $\frac{d F^{ \pm}}{d x}$ values give the net rate of infragravity energy flux gain or loss.

[11] The gradients of shoreward energy flux averaged over low and high tides indicate there is a net increase in $F^{+}$in the shoaling region and the outer surfzones (curves in Figure $3 \mathrm{a}, \frac{d F^{+}}{d x}>0$ for $\left.x_{s z}>0.7\right)$ and a net loss in the inner surfzone (Figure $3 \mathrm{a}, \frac{d F^{+}}{d x}<0$ for $x_{s z}<0.7$ ). The inner-surfzone losses (i.e., the area under the curves for $x_{s z}<$ 0.7 in Figure 3a) during low tide are several times larger than during high tide, reducing the amount of infragravity energy available for reflection at the shoreline, and producing the reduction in $F^{-}$(Figure 2a) and total variance (Figure 1a) observed offshore. Gradients in the seaward energy fluxes $\frac{d F^{-}}{d x}$ are small at low and high tides (not
shown).

\subsection{Nonlinear Energy Balance}

[12] In shallow water, near-resonant nonlinear interactions result in rapid energy transfers between triads of surface-gravity waves [Freilich and Guza, 1984]. The change in energy flux at frequency $f$ consists of contributions from interactions with pairs of waves such that the sum or difference of their frequencies equals $f$. Using

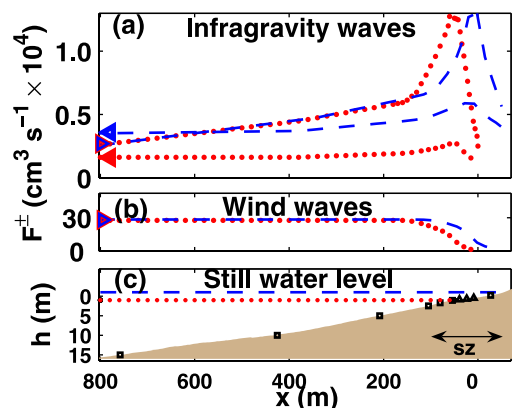

Figure 2. (a) Infragravity and (b) wind-wave energy flux $\left(\mathrm{cm}^{3} \mathrm{~s}^{-1}\right)$ and (c) water depth (m) versus cross-shore distance (m). Symbols in (c) show the locations of colocated pressure gages and current meters deployed for a 21-day period (squares) that included 4 days (triangles) of additional instrumentation in the surfzone (region labeled 'sz'). Energy fluxes are means from approximately 45 high (blue-dashed curves) and 45 low (red-dotted curves) tide 1-hr data records spanning the 21-day period. Shoreward ("upper" curves with right-pointing triangles) and seaward ("lower" curves with left-pointing triangles) infragravity energy fluxes are shown in Figure 2a, whereas only shoreward wind-wave energy flux is shown in Figure $2 \mathrm{~b}$ because the seaward windwave energy flux is negligible. 


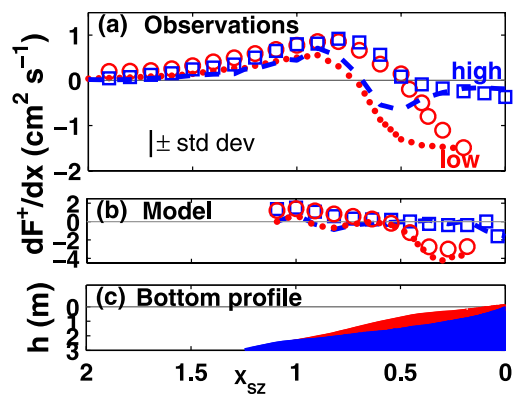

Figure 3. Shoreward infragravity frequency energy flux gradients $\frac{d F^{+}}{d x}$ from (a) observations and (b) numerical model simulations, and (c) water depth at low (red) and high (blue) tide versus normalized surfzone location $\left(x_{s z}\right)$. The energy flux gradients $\frac{d F^{+}}{d x}$ are estimated from differences in the flux $\left(F^{+}\right.$, equation (1)) between neighboring locations (red-dotted curves are low tide, blue-dashed curves are high tide) and from nonlinear transfers (equation (2)) at each location (red circles are low tide, blue squares are high tide). The values in Figure $3 \mathrm{a}$ are means of 45 1-hr records at each tide stage, with \pm 1 standard deviation shown in the lower left. Tests of resolution sensitivity using a subset ( 8 cases each of high and low tide) of the data with 3 additional instruments in the cross-shore array confirm the validity of the gradient method. The results in Figure $3 \mathrm{~b}$ are from a numerically simulated case study [hence the difference in vertical scale from the averages in Figure 3a] using the nonlinear shallow water equations at low (red dotted) and high (blue dashed) tide with identical incident waves, but different bottom profiles. Also included in Figure $3 \mathrm{~b}$ are estimates of the nonlinear energy transfers (equation (2)) obtained from the simulated time series [similar to the symbols in Figure 3a]. The cross-shore coordinate is normalized by the surfzone width, such that $x_{s z}=0$ where the still water intersects the beach and $x_{s z}=1$ where waves begin to break.

a slowly varying (i.e., WKB), weakly-nonlinear energy balance [Herbers and Burton, 1997] based on the inviscid Boussinesq equations [Peregrine, 1967], the net change in shoreward energy flux $F^{+}$at frequency $f$ is proportional to the integral of the imaginary part of the bispectrum $B$ [Hasselmann et al., 1963; Elgar and Guza, 1985] over all frequency pairs $\left(f^{\prime}, f-f^{\prime}\right)$ with sum frequency $f$, such that [Norheim et al., 1998, equation (1) in flux form],

$$
\frac{d F^{+}}{d x}=\int\left(\frac{3 \pi f}{h} \int_{-\infty}^{+\infty} \operatorname{Im}\left[B\left(f^{\prime}, f-f^{\prime}\right)\right] d f^{\prime}\right) d f
$$

where the outer integral is over the infragravity frequency range to match the flux calculation (equation (1)). The dominant exchange with an infragravity frequency $f$ occurs within the triad $\left(f^{\prime}, f-f^{\prime}, f\right)$ where both $f^{\prime}$ and $f-f^{\prime}$ are in the wind-wave frequency range and have opposite signs (i.e., a difference interaction). Here, nonlinear transfers are assigned to $F^{+}$, and the small observed changes in $F^{-}$are neglected (consistent with the large resonance-mismatch between shoreward-propagating wind waves and seawardpropagating infragravity waves [Freilich and Guza, 1984]).

[13] Seaward of the surfzone $\left(x_{s z}>1\right.$, Figure 3a), the rates of infragravity energy flux gain estimated using equation (1) are approximately equal to the nonlinear triad energy exchange rates (equation (2)) at both low and high tides, consistent with previous studies of random waves on a natural beach [Norheim et al., 1998; Herbers et al., 2000]. In the surfzone $\left(x_{s z}<1\right.$, Figure $\left.3 \mathrm{a}\right)$, the rates of infragravity energy flux loss estimated using equation (1) also are approximately equal (although shifted seaward) to the nonlinear triad energy exchange rates (equation (2)). In particular, the increased loss rate observed (equation (1)) during low tide is explained well by nonlinear transfers (equation (2)) (Figure 3a). On average, when integrated over the cross-shore transect, nonlinear transfers account for more than half of the net changes in infragravity energy flux at both low (net energy loss) and high (net energy gain) tides, and for more than $70 \%$ of the tidal modulation of

infragravity energy flux.
$[14]$ Estimates of the biphase $\left(\phi=\arctan \frac{\operatorname{Im}[B]}{\operatorname{Re}[B]}\right)$ between infragravity and wind waves (not shown) are consistent with the known evolution from $\phi=-180$ in deep water [Longuet-Higgins and Stewart, 1962] toward $\phi=0$ with decreasing depth [Elgar and Guza, 1985; Battjes et al., 2004], and to $\phi>0$ in water depths less than about $1 \mathrm{~m}$, where infragravity energy is lost to higher frequencies.

[15] Although tidal modulations were absent, previous studies on the North Carolina coast [Henderson and Bowen, 2002] identified similar cross-shore regions and rates of net infragravity gain and loss, and suggested that bottom drag may account for the observed losses. Equation (2) neglects bottom drag, and instead demonstrates that nonlinear energy exchanges between infragravity and wind waves explain most of the infragravity losses, similar to a concurrent study on the North Carolina coast (Henderson et al., submitted manuscript, 2006). Although the WKB assumption of slow variations used to derive equation (2) may be violated near the shoreline on the steep North Carolina beach, for the relatively gently sloping beach here $\left(\frac{d h}{d x}<0.02\right.$ for $1.0<h<$ $0.3 \mathrm{~m}$ during all tidal levels), the deviations in energy transfers from the WKB approximation are estimated to be less than $10 \%$.

\subsection{Numerical Model}

[16] The nonlinear transfers that reduce infragravity energy in the surfzone are simulated in a numerical model based on the fully nonlinear shallow water equations with Lax-Wendroff dissipation at bore fronts and quadratic bottom drag [Wurjanto and Kobayashi, 1991; Raubenheimer et al., 1995]. The model was initialized with a 1-hr time series of surface elevation (wind-wave variance $=500 \mathrm{~cm}^{2}$ ) calculated from bottom pressures observed in $2.5-\mathrm{m}$ water depth, and run toward the shoreline over both the low- and high-tide bottom profiles (Figure 3c). The cross-shore structure of $\frac{d F^{+}}{d x}$ in the modeled time series (Figure $3 b$ ) is similar to that of the average of the observations (Figure 3a), including the enhanced energy loss at low tide.

[17] Estimates of nonlinear transfers within the model time series (using equation(2)) account for $80 \%$ of the net changes in infragravity energy flux (Figure 3b), implying at most a $20 \%$ contribution from bottom friction and other loss mechanisms (assuming a perfect flux budget). The model results are insensitive to reductions in the bottom drag coefficient from the nominal [Wurjanto and Kobayashi, 
1991; Raubenheimer et al., 1995] value $c_{d}=0.015$. In contrast, in model tests with much larger bottom drag $\left(c_{d}=\right.$ $0.05,0.15)$, bottom dissipation dominates the energy balance, and a tidal modulation is not predicted. Thus, in the numerical model, tidal modulation is caused by differences in nonlinear energy transfers over the low- and high-tide bottom profiles (Figure 3c) and not by differences in bottom dissipation.

\subsection{Bottom Profile Dependence}

[18] Nonlinear transfers of infragravity energy to motions with higher frequencies were observed only in water depths less than about $1 \mathrm{~m}$. The triad interactions are closer to resonance with decreasing depth and require space to transfer energy [Freilich and Guza, 1984; Herbers et al., 1995a]. Thus, although the total surfzone width does not change with the tide, the $h^{-1}$ dependence of nonlinear triad exchanges (equation (2)) predicts enhanced energy transfers over the convex low-tide bottom profile (compared with the concave high-tide profile), because the horizontal extent $\left(\int h^{-1}(x) d x\right)$ of the shallow $(h<1 \mathrm{~m})$ region is greater at low tide (Figure $3 \mathrm{c})$. The tidal modulation of infragravity energy observed in 5-m water depth at eight other transects spanning $1.5 \mathrm{~km}$ of the coast is consistent with enhanced nonlinear energy transfers over the convex low-tide profiles (not shown).

\section{Conclusions}

[19] Observations and numerical model simulations of ocean surface-gravity waves between 15 -m water depth and the shoreline show that in the surfzone nonlinear wave-wave interactions transfer energy from low-frequency (infragravity), long waves back to higher-frequency motions. The energy transfer is enhanced over the relatively flatter innersurfzone bottom profile at low tide, explaining the tidal modulation of infragravity energy observed in bottompressure records on the southern California continental shelf. Similar tidal changes in beach profiles are common worldwide [Woodroffe, 2002, section 6.2.2], and thus tidal modulation of infragravity energy in the surfzone may affect nearshore processes and regional seismic activity in many areas.

[20] Acknowledgments. Staff from the PVLAB (WHOI), CCS (SIO), and BPRC (OSU) helped obtain the observations. S. Henderson generously provided drafts of a manuscript with complementary findings about nonlinear losses. Support was provided by ONR and NSF.

\section{References}

Battjes, J. A., H. J. Bakkenes, T. T. Janssen, and A. R. van Dongeren (2004), Shoaling of subharmonic gravity waves, J. Geophys. Res., 109, C02009, doi:10.1029/2003JC001863.

Bowen, A., and R. A. Holman (1989), Shear instabilities of the mean longshore current: 1. Theory, J. Geophys. Res., 94, 18,023-18,030.

Dolenc, D., B. Romanowicz, D. Stakes, P. McGill, and D. Neuhausser (2005), Observations of infragravity waves at the Monterey ocean bottom broadband station (MOBB), Geochem. Geophys. Geosyst., 6, Q09002, doi:10.1029/2005GC000988.

Elgar, S., and R. T. Guza (1985), Observations of bispectra of shoaling surface gravity waves, J. Fluid Mech., 161, 425-448.

Elgar, S., T. H. C. Herbers, M. Okihiro, J. Oltman-Shay, and R. T. Guza (1992), Observations of infragravity waves, J. Geophys. Res., 97, $15,573-15,577$.

Elgar, S., T. H. C. Herbers, and R. T. Guza (1994), Reflection of ocean surface waves from a natural beach, J. Phys. Oceanogr., 24, 1503-1511.

Freilich, M. H., and R. T. Guza (1984), Nonlinear effects on shoaling surface gravity waves, Proc. R. Soc. London, Ser. A, 311, 1-41.

Guza, R. T., and E. Thornton (1985), Observations of surf beat, J. Geophys. Res., 90, 3161-3172.
Hasselmann, K., W. Munk, and G. MacDonald (1963), Bispectra of ocean waves, in Time Series Analysis, edited by M. Rosenblatt, pp. 125-139, John Wiley, Hoboken, N. J.

Henderson, S. M., and A. J. Bowen (2002), Observations of surf beat forcing and dissipation, J. Geophys. Res., 107(C11), 3193, doi:10.1029/ 2000JC000498.

Herbers, T. H. C., and M. C. Burton (1997), Nonlinear shoaling of directionally spread waves on a beach, J. Geophys. Res., 102, 21,101-21,114.

Herbers, T. H. C., S. Elgar, and R. T. Guza (1995a), Generation and propagation of infragravity waves, J. Geophys. Res., 100, 24,863-24,872.

Herbers, T. H. C., S. Elgar, R. T. Guza, and W. O'Reilly (1995b), Infragravity-frequency $(0.005-0.05 \mathrm{~Hz})$ motions on the shelf, II, Free waves, J. Phys. Oceanogr., 25, 1063-1079.

Herbers, T. H. C., N. R. Russnogle, and S. Elgar (2000), Spectral energy balance of breaking waves within the surf zone, J. Phys. Oceanogr., 30 , $2723-2737$.

Holman, R. A., and A. J. Bowen (1982), Bars, bumps and holes: Models, J. Geophys. Res., 87, 12,749-12,765.

Huntley, D., R. T. Guza, and E. B. Thornton (1981), Field observations of surf beat: 1. Progressive edge waves, J. Geophys. Res., 86, 6451-6466.

Kobayashi, N., and E. Karjadi (1996), Obliquely incident irregular waves in surf and swash zones, J. Geophys. Res., 101, 6527-6542.

Lippmann, T. C., T. H. C. Herbers, and E. B. Thornton (1999), Gravity and shear wave contributions to nearshore infragravity motions, J. Phys. Oceanogr., 29, 231-239.

Longuet-Higgins, M., and R. Stewart (1962), Radiation stress and mass transport in gravity waves, with application to surf beats, J. Fluid Mech., 13, 481-504

Munk, W., F. Snodgrass, and G. Carrier (1956), Edge waves on the continental shelf, Science, 123, 127-132.

Norheim, C. A., T. H. C. Herbers, and S. Elgar (1998), Nonlinear evolution of surface wave spectra on a beach, J. Phys. Oceanogr., 28, 1534-1551.

Okihiro, M., and R. T. Guza (1995), Infragravity energy modulation by tides, J. Geophys. Res., 100, 16,143-16,148

Oltman-Shay, J., and R. T. Guza (1987), Infragravity edge wave observations on two California beaches, J. Phys. Oceanogr., 17, 644-663.

Oltman-Shay, J., P. Howd, and W. Birkeimeir (1989), Shear instability of the mean longshore current: 2. Field observations, J. Geophys. Res., 94, $18,031-18,042$.

Peregrine, D. H. (1967), Long waves on a beach, J. Fluid Mech., 27, $815-$ 827.

Rabinovich, A., and F. Stephenson (2004), Longwave measurements for the coast of British Columbia and improvements to the tsunami warning capability, Nat. Hazards, 32, 313-343.

Raubenheimer, B., R. T. Guza, S. Elgar, and N. Kobayashi (1995), Swash on a gently sloping beach, J. Geophys. Res., 100, 8751-8760.

Rhie, J., and B. Romanowicz (2004), Excitation of Earth's continuous free oscillations by atmosphere-ocean-seafloor coupling, Nature, 431, $552-$ 556.

Sheremet, A., R. T. Guza, S. Elgar, and T. H. C. Herbers (2002), Observations of nearshore infragravity waves: Seaward and shoreward propagating components, J. Geophys. Res., 107(C8), 3095, doi:10.1029/ 2001JC000970.

Tanimoto, T. (2005), The oceanic excitation hypothesis for the continuous oscillation of the Earth, Geophys. J. Int., 160, 276-288.

Tucker, M. (1950), Surf beats: Sea waves of 1 to 5 minute period, Proc. $R$. Soc. London, Ser. A, 202, 565-573.

Van Dongeren, A. P., J. Van Noorloos, K. Steenhauer, J. Battjes, T. Janssen, and A. Reniers (2004), Shoaling and shoreline dissipation of subharmonic gravity waves, paper presented at International Conference on Coastal Engineering, Coastal Eng. Res. Counc., Coasts, Oceans, Ports, Rivers Inst. , Am. Soc. of Civ. Eng., Lisbon, Portugal.

Webb, S., X. Zhang, and W. Crawford (1991), Infragravity waves in the deep ocean, J. Geophys. Res., 96, 2723-2736.

Woodroffe, C. D. (2002), Coasts: Form Process and Evolution, Cambridge Univ. Press, New York.

Wurjanto, A., and N. Kobayashi (1991), Numerical model for random waves on impermeable coastal structures and beaches, Res. Rep CACR-91-05, Cent. for Appl. Coastal Res., Univ. of Del., Newark.

J. Thomson, Woods Hole Oceanographic Institution, MS 9, Woods Hole, MA 02543, USA. (jthomson@whoi.edu)

S. Elgar, Woods Hole Oceanographic Institution, MS 11, Woods Hole, MA 02543,USA. (elgar@whoi.edu)

B. Raubenheimer, Woods Hole Oceanographic Institution, MS 12 , Woods Hole, MA 02543, USA. (braubenheimer@whoi.edu)

T. H. C. Herbers, Naval Postgraduate School, Code OC/He, Monterey, CA 93943, USA. (thherber@nps.edu)

R. T. Guza, Scripps Institution of Oceanography, La Jolla, CA 92093 USA. (rtg@coast.ucsd.edu) 